powinności. Sądzę, iż Autor z niezwykłą intuicją i wyczuciem zastosował owo zalecenie. W konsekwencji dał on obraz Hessena jako dynamicznej, bogatej duchowo, wszechstronnej, twórczej, krytycznej, ale przede wszystkim odpowiedzialnej i wolnej osobowości.
Reasumując, recenzowana monografia zasługuje na szczególną uwage i pełne uznanie. Stanowi ona bowiem, zarówno w swej warstwie merytorycznej jak i metodologicznej, bezsporny i bardzo cenny wkład w rozwój badań nad historią myśli pedagogicznej.

Anna Walczak

\title{
Noty
}

\section{Album studentów Akademii Zamojskiej (1595-1781), oprac. H. Gmiterek, Archiwum Dziejów Oświaty, t. 11, red. K. Bartnicka, Warszawa 1994,
ss. 604.}

W kolejnym tomie wydanym przez Instytut Historii Nauki PAN otrzymaliśmy cenne źródło do badania dziejów oświaty okresu staropolskiego - album wpisów Akademii Zamojskiej. Sprzyjała tej publikacji rocznica powstania uczelni. Mija bowiem już okrągłe 400 lat od czasu powołania do życia przez kanclerza Jana Zamoyskiego szkoły, której zadaniem było przygotowanie młodzieży szlacheckiej do działalności dla dobra Rzeczypospolitej. W 1594 roku papież Klemens VIII zezwolił na powołanie szkoły, w roku następnym natomiast - 15 marca 1595 uroczyście otworzono Akademię. Przez mury tej szkoły przewinał się cały szereg ważnych dla naszych dziejów osób.

Księge wpisów prowadzono w Zamościu od początku istnienia szkoły, wpisywano do niej wszystkich uczniów szkoły. $\mathrm{Na}$ przestrzeni lat 1595-1781 zaledwie przez około 30 lat nie prowadzono albumu. Lącznie wpisano 10552 osoby. Przez większość czasu nie podawano do jakiej klasy należała dana osoba, wpis świadczył po prostu - rozpoczęciu nauki w szkole. Podawano imię i imię ojca, nazwisko i pochodzenie terytorialne (województwo, powiat, diecezja lub po prostu kraj, rzadziej nazwę miasta lub wsi). Niekiedy podawano wysokość wpisowego, adnotację o złożeniu przysięgi, a od 1697 roku - pochodzenie spoleczne i stan ucznia; sporadycznie wiek, wyznanie, liczbę lat $w$ danej klasie itp.

Wśród uczniów przeważała młodzież plebejska, udział szlachty sięgał kilkanaście, niekiedy więcej procent.

Publikacja składa się ze wstẹpu zawierającego podstawowe wiadomości o dziejach Akademii, o samym Albumie i jego zawartości, studentach $w$ jego świetle. Następnie zamieszczony jest spis rektorów Akademii, zestawienie ilości studentów w poszczególnych latach, wykaz promocji z podziałem na doktoraty filozofii, obojga praw, teologii, magisterium filozofii, bakalaureat sztuk wyzwolonych, notariaty publiczne i apostolskie. Zasadniczą część stanowi album studentów. Uzupełnieniem jest indeks osób i nazw geograficznych oraz ilustracje związane z dziejami Akademii.

Publikacja ta stanowi cenne źródło do badania dziejów okresu staropolskiego. Przede wszystkim do badania dziejów wychowania, ale również do badań biograficznych. Pomaga analizować oddziaływanie szkoły na społeczeństwo.

Dorota Żolqdź 